\title{
Hubungan antara Kebiasaan Melewatkan Sarapan, Konsumsi Sayur Buah dan Fast Food, Aktivitas Fisik, Aktivitas Sedentary dengan Kejadian Gizi Lebih
}

\author{
Noerfitri, Tivanny Winoto Putri, Rizki Ugi Febriati \\ STIKes Mitra Keluarga
}

\begin{abstract}
Abstrak
Latar belakang: Peningkatan kejadian gizi lebih remaja karena penurunan aktivitas fisik dan peningkatan konsumsi makanan yang mengandung lemak dan karbohidrat tinggi di mana makanan tersebut memiliki nilai gizi rendah. Indonesia termasuk 10 negara dengan prevalensi kelebihan gizi terbesar di dunia. Salah satu provinsi yang mengalami gizi lebih melebihi prevalensi gizi lebih adalah Jawa Barat. Penelitian ini bertujuan mengetahui faktorfaktor yang berhubungan dengan kejadian gizi lebih remaja di Sekolah Tinggi Ilmu Kesehatan (STIKes) Mitra Keluarga Bekasi.

Metode: Penelitian ini menggunakan desain cross-sectional, dengan variabel independen kebiasaan melewatkan sarapan, konsumsi sayur dan buah, konsumsi fast food, aktivitas fisik, dan aktivitas sedentary. Sedangkan variabel dependennya status gizi lebih dengan indikator IMT $\geq 23 \mathrm{~kg} / \mathrm{m}^{2}$. Populasi studi meliputi 450 mahasiswa STIKes Mitra Keluarga Bekasi berusia 17-20 tahun. Data dikumpulkan pada Juni-Juli 2020 dengan sampel sebanyak 215 responden yang dipilih secara consecutive sampling. Uji statistik yang digunakan regresi logistik sederhana.

Hasil: Sebagian besar responden berjenis kelamin perempuan (95,3\%), berusia 19 tahun (46,0\%) dan program studi SI-Keperawatan (32,6\%). Hasil uji regresi logistik mendapatkan p-value pada tiap variabel yaitu kebiasaan melewatkan sarapan (0,353), konsumsi sayur (0,721), konsumsi buah (0,853), konsumsi fast food $(0,867)$, aktivitas fisik $(0,828)$, aktivitas sedentary sedang $(0,734)$, aktivitas sedentary berat $(0,090)$.

Kesimpulan: Kebiasaan melewatkan sarapan, konsumsi sayur buah, konsumsi fast food, aktivitas fisik serta aktivitas sedentary tidak berhubungan dengan kejadian gizi lebih pada mahasiswa STIKes Mitra Keluarga.

Kata kunci: aktivitas, fast food, gizi lebih, sarapan, sayur buah

\section{Relationship Between the Habits of Skipped Breakfast, Consumption of Vegetables Fruits and Fast Food, Physical Activities, Sedentary Activities with Overnutrition}

\begin{abstract}
Background: The increase in the incidence of overnutrition in adolescence due to decreased physical activity and increased consumption of foods with high in fat and high in carbohydrates, which these foods have low nutritional value. Indonesia is one of the 10 countries with the highest prevalence of overweight in the world. One of the provinces experiencing overnutrition above the prevalence of overnutrition in Indonesia is West Java. This study aims to determine the factors associated with the incidence of overnutrition in STIKes Mitra Keluarga Bekasi.

Methods: This study used a cross-sectional design. The independent variable was habit of skipping breakfast, consumption of vegetables, fruits, consumption of fast food, physical activity, sedentary activity, while the dependent variable was over nutritional status with BMI indicators $\geq 23 \mathrm{~kg} / \mathrm{m}^{2}$. The study population was 450 STIKes Mitra Keluarga Bekasi students aged 17-20 years. Data collection was carried out in June-July 2020 with a sample of 215 respondents who were selected by consecutive sampling. To determine the relationship between the two variables studied, the data were analyzed using a Simple Logistic Regression test.

Result: Most of the respondents were female (95.3\%), 19 years old (46.0\%), SI-Nursing study program (32.6\%). Simple Logistic Regression test results obtain p-value for each variable is the habit of skipping breakfast (0.353), vegetables consumption (0.721), fruits consumption (0.853), fast food consumption (0.867), physical activity (0.828), moderate sedentary activity (0.734), and heavy sedentary activity (0.090).

Conclusion: There is no relationship between the habit of skipping breakfast, consumption of vegetables, fruits, and fast food, physical activity and sedentary activity with overnutrition in STIKes Mitra Keluarga students.

Keywords:Activities, fast food, overnutrition, breakfast, fruits vegetables

$\begin{array}{ll}\text { Korespondensi } & \text { : Noerfitri } \\ \text { Email } & \text { : noerfitri@stikesmitrakeluarga.ac.id }\end{array}$
\end{abstract}




\section{PENDAHULUAN}

Belum tuntasnya penanganan masalah gizi kurang yang dihadapi oleh Indonesia, kini permasalahan gizi lebih (overnutrition) harus pula dihadapi Indonesia ${ }^{1}$. Kejadian gizi lebih meningkat pada usia remaja karena menurunnya aktivitas fisik dan meningkatnya konsumsi makanan yang mengandung karbohidrat dan lemak yang tinggi di mana makanan tersebut memiliki nilai gizi yang rendah ${ }^{2}$. Penelitian yang dilakukan pada remaja di Kanada didapatkan hasil sekitar 95\% dari remaja tidak melakukan aktivitas fisik yang direkomendasikan ${ }^{3}$. Menurut hasil penelitian yang dilakukan di Medan, sebanyak $55 \%$ remaja memiliki pola makan yang tidak baik. ${ }^{4}$ Menurut hasil RISKESDAS tahun 2018 ada sekitar 96,4\% remaja yang kurang mengkonsumsi sayur buah ${ }^{5}$.

Berdasarkan hasil systematic review pada tahun 2013 yang melibatkan 188 negara ditemukan 10 negara dengan prevalensi gizi lebih terbanyak di dunia. Lebih dari $50 \%$ dari 671 juta orang gemuk di Asia dunia hidup di sepuluh negara tersebut ${ }^{6}$. Berdasarkan data RISKESDAS tahun 2018, prevalensi remaja (1618 tahun) yang mengalami gizi lebih menurut Indeks Massa Tubuh (IMT) sebesar 13,6\%, hal tersebut naik dari tahun 2013 sebesar 11,5\%. Adapun prevalensi dewasa ( $>18$ tahun) yang mengalami gizi lebih adalah sebesar $35,4 \%$, angka tersebut naik dari tahun 2013 sebesar $28,7 \%$. Salah satu provinsi yang mengalami gizi lebih di atas prevalensi gizi lebih di Indonesia adalah Jawa Barat ${ }^{5}$. Prevalensi remaja dan dewasa yang mengalami gizi lebih di Jawa Barat masing-masing sebesar $15,4 \%$ dan $36,0 \%$. Kota Bekasi termasuk dalam 12 kabupaten/kota dengan prevalensi gemuk pada remaja 16-18 tahun di atas angka prevalensi Jawa Barat ${ }^{7}$.

Gizi lebih pada remaja umumnya disebabkan oleh multifaktor diantaranya faktor kebiasaan melewatkan sarapan, konsumsi fast food, konsumsi sayur dan buah, aktivitas fisik, dan perilaku sedentary. ${ }^{8-15}$ Kebiasaan melewatkan sarapan terbukti menjadi salah satu faktor penyebab terjdinya gizi lebih ${ }^{16}$. Faktor lain yang mempengaruhi kejadian obesitas adalah konsumsi fast food. Anak yang sering mengkonsumsi fast food lebih berisiko mengalami obesitas dibandingkan anak yang jarang mengkonsumsi fast food ${ }^{11}$. Selain itu, konsumsi sayur dan buah yang rendah juga berhubungan dengan kejadian gizi lebih. ${ }^{14}$

Faktor lain yang juga berpengaruh terhadap kejadian gizi lebih adalah aktivitas sedentari ${ }^{13}$. Perilaku sedentary adalah perilaku santai antara lain duduk, berbaring, dan lain sebagainya dalam sehari-hari baik di tempat kerja, di rumah, maupun di perjalanan/ transportasi tetapi tidak termasuk waktu tidur ${ }^{17}$. Menurut hasil penelitian yang dilakukan di Manado terdapat korelasi negatif antara aktivitas fisik yang dilakukan dengan status gizi, semakin ringan aktivitas fisiknya makan akan semakin besar IMT/U ${ }^{18}$.

Dari uraian di atas, penting untuk meneliti faktor-faktor yang berhubungan dengan kejadian gizi lebih pada remaja yang berstatus mahasiswa/mahasiswi di Sekolah Tinggi Ilmu Kesehatan (STIKes) Mitra Keluarga Bekasi. Penulis memilih lokasi STIKes Mitra Keluarga Bekasi sebagai lokasi penelitian dikarenakan STIKes Mitra Keluarga Bekasi merupakan perguruan tinggi yang berlokasi di daerah perkotaan, sehingga remaja tersebut memiliki risiko lebih besar mengalami gizi lebih dibandingkan dengan remaja yang berada di perdesaan ${ }^{19}$.

\section{METODE}

Penelitian ini menggunakan desain crosssectional. Variabel independen yang diteliti adalah kebiasaan melewatkan sarapan, konsumsi sayur dan buah, konsumsi fast food, aktivitas fisik, dan aktivitas sedentary, sedangkan variabel dependennya adalah status gizi lebih dengan indikator IMT $\geq 23 \mathrm{~kg} / \mathrm{m}^{2}$. Populasi studi sebanyak 450 mahasiswa STIKes Mitra Keluarga Bekasi yang berusia 17-20 tahun. Pengambilan data dilakukan pada bulan Juni-Juli 2020 dengan jumlah sampel sebanyak 215 responden yang dipilih secara consecutive sampling, sesuai kriteria penelitian hingga jumlah sampel terpenuhi sampai dengan waktu yang ditentukan ${ }^{20}$. Kriteria inklusi yaitu Mahasiswa STIKes Mitra Keluarga yang berusia 17-20 tahun dan bersedia berpartisipasi pada penelitian. Kriteria eksklusi yaitu mahasiswa STIKes Mitra Keluarga dengan status gizi kurang, memiliki penyakit kronik dan akut, serta sedang menjalani diet khusus. 
Data primer yang dikumpulkan meliputi karakteristik yang terdiri dari jenis kelamin, usia dan program studi responden, frekuensi sarapan, konsumsi sayur dan buah, konsumsi fast food, aktivitas fisik, dan aktivitas sedentary, data antropometri Berat Badan (BB) dan Tinggi Badan (TB) diperoleh melalui pengukuran tidak langsung. Data konsumsi fast food, sayur dan buah diperoleh dari responden yang mengisi formulir Food Frequency Questionnaire (FFQ). Kategori frekuensi fast food dibagi menjadi dua, yaitu tidak sering $<2 \mathrm{x} /$ minggu, dan Sering $\geq 2 \mathrm{x} /$ minggu. Kategori frekuensi konsumsi sayur dan buah dibagi menjadi dua, yaitu sayur dengan kategori kurang 3 kali/hari, sedangkan buah dengan kategori kurang $2 \mathrm{kali} / \mathrm{hari}^{21}$. Data aktivitas fisik diperoleh dari responden yang mengisi kuesioner Physical Activity Questionnaire for Adolescents (PAQ-A) yang berisi pernyataan mengenai aktivitas fisik yang dilakukan sehari-hari selama kurun waktu 7 hari yang lalu. Pada kuesioner PAQ-A, ada 9 butir pertanyaan. Kategori aktivitas fisik dibagi menjadi dua yaitu aktivitas kurang jika Skor 0-2 dan aktivitas cukup jika skor 3-5. Aktivitas sedentary menggunakan formulir 24 Hour Physical Activity Recall (PAR) untuk mengukur aktivitas sedentary selama seminggu. Kategori aktivitas sedentary dibagi menjadi tiga, yaitu ringan $(1,40-1,69)$, sedang $(1,70-1,99)$, dan berat $(2,00-2,40) .^{22}$ Variabel dependen yang menjadi fokus penelitian adalah status gizi lebih. Data gizi lebih diperoleh dengan pengukuran IMT dengan rumus $\mathrm{BB}$ dibagi $\mathrm{TB}$ dalam meter $^{2}$. BB diukur menggunakan Timbangan dan TB diukur menggunakan Microtoise. Dapat dikatakan gizi lebih jika nilai $\mathrm{IMT} \geq 23 \mathrm{Kg} / \mathrm{m}^{223}$. Analisis hubungan variabel independen dan variabel dependen dilakukan uji statistik regresi logistik sederhana.

Surat lolos kaji etik telah didapatkan dari Komisi Etik Penelitian Universitas Muhammadiyah Prof. Dr. Hamka dengan nomor 03/20.04/0446.

\section{HASIL}

Hasil penelitian ini menunjukkan bahwa sebagian besar responden berjenis kelamin perempuan $(95,3 \%)$. Usia responden berkisar antara 18-20 tahun, mahasiswa yang paling banyak menjadi responden adalah mahasiswa berusia 19 tahun sebesar 46,0\%. Responden berasal dari 5 program studi yang ada di STIKes Mitra Keluarga, mahasiswa yang menjadi responden paling banyak berasal dari program studi S-I Keperawatan sebesar 32,6\%, sedangkan yang paling sedikit berasal dari program studi D-III Keperawaatan sebesar 2,3\% (Tabel 1).

\begin{tabular}{|c|c|c|}
\hline Karakteristik & $\begin{array}{c}\text { Jumlah } \\
(\mathbf{n})\end{array}$ & $\begin{array}{c}\text { Persentase } \\
(\%)\end{array}$ \\
\hline \multicolumn{3}{|l|}{ Jenis kelamin } \\
\hline Laki-laki & 10 & 4,7 \\
\hline Perempuan & 205 & 95,3 \\
\hline \multicolumn{3}{|l|}{ Usia } \\
\hline 18 tahun & 34 & 15,8 \\
\hline 19 tahun & 99 & 46,0 \\
\hline 20 tahun & 82 & 38,1 \\
\hline \multicolumn{3}{|l|}{ Program studi } \\
\hline D-III Keperawatan & 5 & 2,3 \\
\hline S-I Gizi & 54 & 25,1 \\
\hline D-III TLM ${ }^{1}$ & 38 & 17,7 \\
\hline S-I Farmasi & 48 & 22,3 \\
\hline S-I Keperawatan & 70 & 32,6 \\
\hline
\end{tabular}

${ }^{1} \mathrm{TLM}=$ Teknologi Laboratorium Medis

Berdasarkan tabel 2 responden yang mengalami gizi lebih sebesar 40,0\%. Mayoritas responden tidak melewatkan sarapan $(64,2 \%)$, sudah cukup mengkonsumsi sayur $(81,4 \%)$ dan cukup mengkonsumsi buah $(71,6 \%)$, dan tidak sering mengkonsumsi fast food $(51,6 \%)$. Mayoritas responden memiliki aktivitas fisik yang kurang $(81,9 \%)$ dan paling banyak responden memiliki aktivitas sedentary yang ringan $(47,0 \%)$ (Tabel 2).

\section{Tabel 2 Distribusi Frekuensi Responden Berdasarkan Variabel Independen dan Variabel Dependen di STIKes Mitra Keluarga Tahun 2020}

\begin{tabular}{lcc}
\hline \multicolumn{1}{c}{ Karakteristik } & $\begin{array}{c}\text { Jumlah } \\
(\mathbf{n})\end{array}$ & $\begin{array}{c}\text { Persentase } \\
(\mathbf{\%})\end{array}$ \\
\hline Gizi lebih & & \\
Ya & 86 & 40,0 \\
Tidak & 129 & 60,0 \\
Kebiasaan & & \\
Melewatkan & 77 & 35,8 \\
Sarapan & 138 & 64,2 \\
Ya & & \\
\hline
\end{tabular}




\begin{tabular}{ccc}
\hline Tidak & & \\
Konsumsi sayur & & \\
Kurang & 40 & 18,6 \\
Cukup & 175 & 81,4 \\
Konsumsi buah & & \\
Kurang & 61 & 28,4 \\
Cukup & 154 & 71,6 \\
Konsumsi Fast food & & \\
$\quad$ Sering & 104 & 48,4 \\
Tidak Sering & 111 & 51,6 \\
Aktivitas Fisik & & \\
Kurang & 176 & 81,9 \\
Cukup & 39 & 18,1 \\
Aktivitas sedentary & & \\
Ringan & 101 & 47,0 \\
Sedang & 71 & 33,0 \\
Berat & 43 & 20,0 \\
\hline
\end{tabular}

Berdasarkan tabel 3 dapat diketahui bahwa dari 77 mahasiswa yang terbiasa melewatkan sarapan terdapat 34 mahasiswa $(44,2 \%)$ yang berstatus gizi lebih, sedangkan dari 148 mahasiswa yang terbiasa sarapan terdapat 52 mahasiswa $(37,7 \%)$ yang mengalami gizi lebih. Analisis dengan uji regresi logistik sederhana menunjukkan tidak ada hubungan antara kebiasaan melewatkan sarapan dengan kejadian gizi lebih di STIKes Mitra Keluarga tahun 2020 ( $p$-value $>0,05)$.

Dari 40 mahasiswa yang memiliki konsumsi sayur kurang terdapat 17 mahasiswa $(42,5 \%)$ yang berstatus gizi lebih, sedangkan dari 175 mahasiswa yang memiliki konsumsi sayur cukup terdapat 69 mahasiswa $(39,4 \%)$ yang berstatus gizi lebih. Analisis dengan uji regresi logistik sederhana diketahui bahwa tidak ada hubungan antara konsumsi sayur dengan kejadian gizi lebih di STIKes Mitra Keluarga tahun 2020 ( $p$-value $>0,05$ ).

Dari 61 mahasiswa yang memiliki konsumsi buah kurang terdapat 25 mahasiswa $(41,0 \%)$ yang berstatus gizi lebih, sedangkan dari 154 mahasiswa yang memiliki konsumsi buah cukup terdapat 61 mahasiswa $(39,6 \%)$ yang berstatus gizi lebih. Analisis dengan uji regresi logistik sederhana diketahui bahwa tidak ada hubungan antara konsumsi buah dengan kejadian gizi lebih di STIKes Mitra Keluarga tahun 2020 ( $p$-value $>0,05)$.

Dari 104 mahasiswa yang sering mengkonsumsi fast food terdapat 41 mahasiswa $(39,4 \%)$ yang berstatus gizi lebih, sedangkan dari 111 mahasiswa yang sering mengkonsumsi fast food terdapat 45 mahasiswa $(40,5 \%)$ yang berstatus gizi lebih. Analisis dengan uji regresi logistik sederhana diketahui bahwa tidak ada hubungan antara konsumsi fast food dengan kejadian gizi lebih di STIKes Mitra Keluarga tahun 2020 ( $p$-value $>0,05)$.

Dari 176 mahasiswa yang kurang melakukan aktivitas fisik terdapat 71 mahasiswa $(40,3 \%)$ yang berstatus gizi lebih, sedangkan dari 39 mahasiswa yang cukup melakukan aktivitas fisik terdapat 15 mahasiswa $(38,5 \%)$ yang berstatus gizi lebih. Analisis dengan uji regresi logistik sederhana diketahui bahwa tidak ada hubungan antara aktivitas fisik dengan kejadian gizi lebih di STIKes Mitra Keluarga tahun 2020 ( $p$-value $>0,05$ ).

Dari 101 mahasiswa yang memiliki aktivitas sedentary ringan terdapat 46 mahasiswa $(45,5 \%)$ yang berstatus gizi lebih, dari 71 mahasiswa yang memiliki memiliki aktivitas sedentary sedang terdapat 27 mahasiswa $(38,0 \%)$ yang berstatus gizi lebih, sedangkan dari 43 mahasiswa yang memiliki memiliki aktivitas sedentary berat terdapat 13 mahasiswa $(30,2 \%)$ yang berstatus gizi lebih. Analisis dengan uji regresi logistik sederhana pada $\alpha=0,05$ diperoleh $p$-value 0,327 untuk membandingkan odds antara kejadian gizi lebih pada kelompok aktivitas sedentary sedang dengan kelompok aktivitas sedentary ringan, serta diperoleh p-value 0,09 untuk membandingkan odds antara kejadian gizi lebih pada kelompok aktivitas sedentary berat dengan kelompok aktivitas sedentary ringan, dimana kedua $p$-value lebih besar dari $\alpha$. Hal ini menunjukkan bahwa tidak ada hubungan antara aktivitas sedentary dengan kejadian gizi lebih di STIKes Mitra Keluarga tahun 2020. 
Tabel 3 Hubungan antara Kebiasaan Melewatkan Sarapan, Konsumsi Sayur Buah dan Fast Food, Aktivitas Fisik dan Aktifitas Sedentary dengan Kejadian Gizi Lebih di STIKes Mitra Keluarga

Tahun 2020

\begin{tabular}{|c|c|c|c|c|c|c|c|}
\hline \multirow{3}{*}{ Karakteristik } & \multicolumn{4}{|c|}{ Gizi Lebih } & \multirow{3}{*}{ P-value } & \multirow{3}{*}{ OR } & \multirow{3}{*}{$95 \%$ CI OR } \\
\hline & \multicolumn{2}{|c|}{ Ya } & \multicolumn{2}{|c|}{ Tidak } & & & \\
\hline & $\mathbf{n}$ & $\%$ & $\mathbf{n}$ & $\%$ & & & \\
\hline \multicolumn{8}{|l|}{ Kebiasaan Melewatkan Sarapan } \\
\hline Ya & 34 & 44,2 & 43 & 55,8 & 0,353 & 1,308 & $0,742-2,304$ \\
\hline Tidak & 52 & 37,7 & 86 & 62,3 & & & \\
\hline \multicolumn{8}{|l|}{ Konsumsi Sayur } \\
\hline Kurang & 17 & 42,5 & 23 & 57,5 & 0,721 & 1,135 & $0,566-2,278$ \\
\hline Cukup & 69 & 39,4 & 106 & 60,6 & & & \\
\hline \multicolumn{8}{|l|}{ Konsumsi Buah } \\
\hline Kurang & 25 & 41,0 & 36 & 59,0 & 0,853 & 1,059 & $0,579-1,937$ \\
\hline Cukup & 61 & 39,6 & 93 & 60,4 & & & \\
\hline \multicolumn{8}{|l|}{ Konsumsi Fast Food } \\
\hline Sering $(\geq 2 \mathrm{x} /$ minggu $)$ & 41 & 39,4 & 63 & 60,6 & 0,867 & 0,954 & $0,553-1,648$ \\
\hline $\begin{array}{l}\text { Tidak Sering } \\
(<2 \mathrm{x} / \mathrm{minggu})\end{array}$ & 45 & 40,5 & 66 & 59,5 & & & \\
\hline \multicolumn{8}{|l|}{ Aktivitas Fisik } \\
\hline Kurang & 71 & 40,3 & 105 & 59,7 & 0,828 & 1,082 & $0,531-2,205$ \\
\hline Cukup & 15 & 38,5 & 24 & 61,5 & & & \\
\hline \multicolumn{8}{|l|}{ Aktivitas Sedentary } \\
\hline Ringan & 46 & 45,5 & 55 & 54,5 & & & \\
\hline Sedang & 27 & 38,0 & 44 & 62,0 & 0,327 & 0,734 & $0,395-1,362$ \\
\hline Berat & 13 & 30,2 & 30 & 69,8 & 0,090 & 0,518 & $0,242-1,107$ \\
\hline
\end{tabular}

\section{PEMBAHASAN}

\section{Kebiasaan Melewatkan Sarapan}

Hasil dari penelitian ini menunjukkan bahwa kebiasaan melewatkan sarapan tidak ada hubungannya dengan kejadian gizi lebih di STIKes Mitra Keluarga tahun 2020. Akan tetapi, proporsi kejadian gizi lebih lebih besar terjadi pada kelompok yang melewatkan sarapan yaitu sebesar 44,2\% dibandingkan dengan kelompok yang tidak melewatkan sarapan yaitu sebesar $37,7 \%$. Hasil serupa didapatkan pada penelitian yang dilakukan di Surabaya bahwa tidak ada hubungan antara kebiasaan melewatkan sarapan dengan kejadian gizi lebih $(p \text {-value }>0,05)^{24}$. Namun, menurut penelitian lain menunjukkan bahwa kebiasaan melewatkan sarapan ada hubungannya dengan kejadian gizi lebih ( $p$ value <0,05). ${ }^{25}$ Pada hasil penelitian ini menunjukkan bahwa kelompok yag terbiasa melewatkan sarapan memiliki persentase kejadian gizi lebih yang lebih tinggi $(44,2 \%)$ dibandingkan dengan kelompok yang tidak terbiasa melewatkan sarapan $(37,7 \%)$. Penelitian ini hanya mengukur frekuensi sarapan tidak mengukur besarnya asupan energi pada sarapan sehingga tidak dapat dijadikan sebagai patokan faktor yang berhubungan dengan kejadian gizi lebih. ${ }^{26}$

\section{Konsumsi Sayur}

Hasil dari penelitian ini menunjukkan bahwa konsumsi sayur tidak ada hubungannya dengan kejadian gizi lebih di STIKes Mitra Keluarga tahun 2020. Akan tetapi, proporsi kejadian gizi lebih lebih besar terjadi pada kelompok yang kurang mengkonsumsi sayur sebesar 42,5\% dibandingkan dengan kelompok yang cukup mengkonsumsi sayur sebesar $39,4 \%$. Hasil serupa didapatkan pada penelitian terhadap remaja di Yogyakarta yang mendapatkan hasil bahwa konsumsi sayur tidak ada hubungannya dengan kejadian obesitas pada remaja $(p \text {-value }>0,05)^{27}$. Namun, menurut penelitian lain menunjukkan bahwa ada hubungan antara konsumsi sayur dengan kejadian gizi lebih $(p \text {-value }<0,05)^{28}$. Penelitian ini tidak mengukur asupan serat yang terkandung dalam sayur dan buah yang merupakan faktor pencegah terjadinya gizi $\mathrm{lebih}^{26}$. Semakin tinggi serat yang dikonsumsi, maka akan semakin rendah kemungkinan terjadinya gizi lebih. Kurangnya konsumsi sayur 
juga bukan merupakan faktor tunggal penyebab terjadinya gizi lebih, ada faktor lain yang berpengaruh terhadap gizi lebih diantaranya pengetahuan gizi, berlebihnya asupan makanan, kurangnya aktivitas fisik, body image negative, dan jenis kelamin ${ }^{29-31}$.

\section{Konsumsi Buah}

Hasil dari penelitian ini menunjukkan bahwa konsumsi buah tidak ada hubungannya dengan kejadian gizi lebih di STIKes Mitra Keluarga tahun 2020. Akan tetapi, proporsi kejadian gizi lebih lebih besar terjadi pada kelompok yang kurang mengkonsumsi buah sebesar $41,0 \%$ dibandingkan dengan kelompok yang cukup mengkonsumsi buah sebesar 39,6\%. Hasil serupa didapatkan pada penelitian terhadap remaja di Yogyakarta yang menunjukkan bahwa konsumsi buah tidak ada hubungannya dengan kejadian obesitas pada remaja ( $p$-value $>0,05) .{ }^{27}$ Namun, menurut penelitian lain menunjukkan bahwa konsumsi buah berhubungan dengan gizi lebih ( $p$-value $<0,05)^{28}$. Penelitian ini tidak mengukur asupan serat yang terdapat dalam sayur dan buah yang merupakan faktor pencegah terjadinya gizi lebih ${ }^{26}$. Penelitian tersebut menunjukkan bahwa semakin tinggi asupan serat, maka kemungkinan terjadinya gizi lebih akan semakin rendah. Kurangnya konsumsi sayur juga bukan merupakan faktor tunggal terjadinya gizi lebih, ada faktor lain yang berpengaruh terhadap kejadian gizi lebih diantaranya pengetahuan gizi, berlebihnya asupan makanan, kurangnya aktivitas fisik, body image negative, dan jenis kelamin $^{29-31}$.

\section{Konsumsi Fast food}

Hasil dari penelitian ini menunjukkan bahwa konsumsi fast food tidak ada hubungannya dengan kejadian gizi lebih di STIKes Mitra Keluarga tahun 2020. Hasil serupa didapatkan pada penelitian yang dilakukan di Semarang bahwa konsumsi fast food tidak ada hubungannya dengan kejadian gizi lebih $(p \text {-value }>0,05)^{32}$. Namun, menurut penelitian lain menunjukkan bahwa konsumsi fast food berhubungan dengan kejadian gizi lebih ( $p$-value $<0,05)^{33}$. Frekuensi fast food yang dikonsumsi belum cukup dijadikan patokan yang dapat menentukan kejadian gizi lebih ${ }^{34}$.
Ada faktor lain yang berpengaruh terhadap kejadian gizi lebih diantaranya asupan karbohidrat, asupan protein, asupan energi, asupan serat, frekuensi kudapan, pengetahuan tentang gizi, konsumsi makanan ringan, aktivitas fisik ${ }^{12,26,35,36}$.

\section{Aktivitas Fisik}

Hasil penelitian ini menunjukkan aktivitas fisik yang dilakukan tidak ada hubungannya dengan gizi lebih di STIKes Mitra Keluarga tahun 2020. Hasil serupa didapatkan pada penelitian yang dilakukan di Surakarta bahwa aktivitas fisik tidak ada hubungannya dengan kejadian gizi lebih $(p \text {-value }>0,05)^{37}$. Namun, menurut penelitian lain menunjukkan bahwa aktivitas fisik berhubungan dengan kejadian gizi lebih $(p \text {-value }<0,05)^{33}$. Pada penelitian ini ada kecenderungan responden yang memiliki aktivitas fisik kurang untuk mengalami gizi lebih lebih tinggi $(40,3 \%)$ dibandingkan yang memiliki aktivitas fisik cukup $(38,5 \%)$.

\section{Aktivitas Sedentary}

Hasil dari penelitian ini menunjukkan aktivitas sedentary tidak ada hubungannya dengan kejadian gizi lebih di STIKes Mitra Keluarga tahun 2020. Hasil serupa didapatkan pada penelitian terhadap anak SD yang dilakukan di Makassar yang menunjukkan hasil bahwa aktivitas sedentary tidak ada hubungannya dengan kejadian gizi lebih ( $p$ value $>0,05)^{38}$. Namun menurut penelitian yang dilakukan di SDN Karang Pawulang Bandung bahwa gaya hidup sedentary berhubungan dengan kejadian gizi lebih ( $p$-value $<0,05)$. Hal tersebut menunjukkan semakin berat aktivitas sedentary maka status gizi subjek semakin meningkat. Hasil penelitian tersebut menunjukkan bahwa pada saat hari libur, subjek lebih memiliki waktu luang untuk berolahraga, jalan-jalan dengan keluarga dan bermain di luar rumah $^{39}$. Tingginya aktivitas sedentary tidak dapat secara langsung menyebabkan gizi lebih jika tidak disertai dengan asupan lemak yang tinggi. Lemak merupakan zat gizi pembentuk energi yang dapat menghasilkan energi paling tinggi dibandingkan karbohidrat dan protein (1 gram lemak mengandung $9 \mathrm{Kkal}$ ). Oleh sebab itu, asupan lemak penting untuk diperhatikan dalam pola makan ${ }^{40}$. 


\section{KESIMPULAN DAN SARAN}

Disimpulkan bahwa tidak ada hubungan antara kebiasaan melewatkan sarapan, konsumsi sayur buah, konsumsi fast food, aktivitas fisik serta aktivitas sedentary dengan kejadian gizi lebih pada mahasiswa STIKes Mitra Keluarga. Akan tetapi, proporsi kejadian gizi lebih lebih besar terjadi pada kelompok terbiasa melewatkan sarapan, konsumsi sayur dan buah kurang, dan aktivitas fisik kurang dibandingkan kelompok lainnya. Disarankan kepada responden penelitian untuk lebih membiasakan diri untuk melakukan sarapan, cukup mengkonsumsi sayur dan buah serta melakukan aktivitas fisik yang cukup untuk mengurangi terjadinya risiko gizi lebih.

\section{DAFTAR PUSTAKA}

1. Kemenkes RI. Penilaian Status Gizi. Jakarta: Kementerian Kesehatan Republik Indonesia; 2017.

2. Adriani M, Wirjatmadi B. Peranan Gizi dalam Siklus Kehidupan (Pertama). Jakarta: Kencana; 2014.

3. Colley RC, Garriguet D, Janssen I, Craig CL, Clarke J, Tremblay MS. Physical activity of canadian children and youth: Accelerometer results from the 2007 to 2009 canadian health measures survey. Heal Reports. 2011;22(1).

4. Gulo IPK. Gambaran Pola Makan dan Status Gizi Remaja di SMP Advent Lubuk Pakam. Vol. 126. Medan: Program Studi Diploma III, Politeknik Kesehatan Medan Jurusan Gizi; 2019. p. 1-7.

5. Kemenkes RI. Laporan Nasional RISKESDAS 2018. Jakarta; 2019.

6. $\mathrm{Ng} \mathrm{M}$, Fleming $\mathrm{T}$, Robinson $\mathrm{M}$, Thomson B, Graetz N, Margono C, et al. Global, regional, and national prevalence of overweight and obesity in children and adults during 1980-2013: A systematic analysis for the Global Burden of Disease Study 2013. Lancet. 2014;384(9945):76681.

7. Dinas Kesehatan Provinsi Jawa Barat. Profil Kesehatan Provinsi Jawa Barat 2017. 2017.
8. Dwira DH, Hidayati RW. Hubungan Pola Konsumsi Makanan Dengan Status Gizi Mahasiswa Semester IV Jurusan DIV Bidan Pendidik Di Universitas 'Aisyiyah Yogyakarta. Universitas 'Aisyiyah Yogyakarta; 2017.

9. Florence AG. Hubungan Pengetahuan Gizi dan Pola Konsumsi dengan Status Gizi pada Mahasiswa TPB Sekolah Bisnis dan Manajemen Institut Teknologi Bandung. Universitas Pasundan; 2017.

10. Kanah P. Hubungan Pengetahuan Dan Pola Konsumsi Dengan Status Gizi Pada Mahasiswa Kesehatan. Med Technol Public Heal J. 2020;4(2):203-11.

11. Lisbeth N. Hubungan Kejadian Obesitas pada Anak dengan Kebiasaan Mengkonsumsi Makanan Siap Saji di SDIT. Ulul Albab Bekasi. J Ilm Keperawatan STIKes Med Cikarang. 2013;

12. Aini SN. Faktor Risiko Yang Berhubungan Dengan Kejadian Gizi Lebih Pada Remaja Di Perkotaan. Unnes J Public Heal. 2013;2(1).

13. Pribadi PSA, Nurhayati F. Hubungan Antara Aktivitas Sedentari Dengan Status Gizi Siswa Kelas X Man Kota Mojokerto. J Pendidik Olahraga dan Kesehat. 2018;6(2):327-30.

14. Rosita TR. Hubungan tingkat konsumsi buah, sayur dan aktivitas fisik dengan status gizi remaja di SMA Muhammadiyah 1 Semarang. Universitas Muhammadiyah Semarang; 2018.

15. Yusintha AN, Adriyanto A. Hubungan Antara Perilaku Makan dan Citra Tubuh dengan Status Gizi Remaja Putri Usia 15-18 Tahun. Amerta Nutr. 2018;2(2):147.

16. Otaki N, Obayashi K, Saeki K, Kitagawa M, Tone N, Kurumatani N. Relationship between breakfast skipping and obesity among elderly: Cross-sectional analysis of the HEIJO-KYO study. J Nutr Heal Aging. 2017;21(5):501-4.

17. Balitbangkes. Riset Kesehatan Dasar: Riskesdas 2013. Jakarta; 2013.

18. Sorongan CI. Hubungan Antara Aktivitas Fisik Dengan Status Gizi Pelajar Smp Frater Don Bosco Manado. J Kesehat Masy. 2010;2(2):1-5.

19. Hafiza D, Utami A, Niriyah S. Hubungan 
Kebiasaan Makan Dengan Status Gizi Pada Remaja Smp Ylpi Pekanbaru. J Med Hutama. 2020; Vol 02 No:332-42.

20. Dahlan MS. Besar Sampel dan Cara Pengambilan Sampel dalam Penelitian Kedoteran dan Kesehatan. Jakarta: Salemba Medika; 2016.

21. Lestari AD. Faktor-faktor yang berhubungan dengan perilaku konsumsi buah dan sayur pada siswa SMP Negeri 226 Jakarta Selatan Tahun 2012. Universitas Islam Negeri Syarif Hidayatullah Jakarta; 2015.

22. Febriani RT. Analisi faktor yang mempengaruhi status gizi lebih remaja di Kota Malang. Universitas Jember; 2018.

23. WHO. Appropriate body-mass index for Asian populations and its implications for policy and intervention strategies. Lancet. 2004;363:157-63.

24. Irdiana W, Nindya TS. Hubungan Kebiasaan Sarapan dan Asupan Zat Gizi dengan Status Gizi Siswi SMAN 3 Surabaya. Amerta Nutr. 2017;1(3):227.

25. Rosida H. Hubungan Kebiasaan Sarapan, Tingkat Kecukupan Energi Dan Gizi Makro Dengan Status Gizi Pada Siswa Pondok Pesantren Al-Fattah Buduran, Sidoarjo. Media Gizi Indones. 2018;12(2):116.

26. Maharani M. Aktivitas Fisik, Pengetahuan Gizi, Asupan Energi, Asupan Serat Dan Status Gizi Lebih Pada Remaja. J Media Kesehat. 2018;10(2):167-72.

27. Karyawati. Hubungan antara konsumsi sayur dan buah dengan kejadian obesitas pada remaja di SMA Muhammadiyah 3 Yogyakarta. Universitas Alma Ata Yogyakarta; 2016.

28. Yanto N, Verawati B, Muchtar D. Hubungan konsumsi buah dan sayur dengan kejadian gizi lebih pada tenaga kesehatan dan tenaga non kesehatan 1. J Ners Vol. 2020;4(23):1-10.

29. Simanungkalit SF. Determinan Gizi Lebih pada Remaja di SMP YPI Bintaro Jakarta. J Ilmu Kesehat Masy. 2019;8(01):25-9.

30. Ruslie RH, Darmadi D. Analisis Regresi Logistik Untuk Faktor-Faktor Yang Mempengaruhi Status Gizi Remaja. Maj Kedokt Andalas. 2012;36(1):62.

31. Suhartini S, Ahmad A. Analisis Faktor
Yang Berhubungan Dengan Status Gizi Remaja Putri Pada Siswi Kelas Vii Smpn 2 Desa Tambak Baya Kecamatan Cibadak Kabupaten Lebak Tahun 2017. J Med (Media Inf Kesehatan). 2018;5(1):72-82.

32. Setyawati VAV, Rimawati E. Pola Konsumsi Fast Food Dan Serat Sebagai Faktor Gizi Lebih Pada Remaja. Unnes J Public Heal. 2016;5(3):275.

33. Armadani DI. Hubungan Antara Konsumsi Fast Food,Aktivitas Fisik, Dan Status Gizi (Secara Genetik) Dengan Gizi Lebih (Studi Pada Siswa Kelas Vii, Viii, Dan Ix Di Mts. Budi Dharma, Wonokromo, Surabaya). J Pendidik Olahraga dan Kesehat. 2017;5(3):766-73.

34. Adriani M, Wirjatmadi B. Peranan Gizi dalam Siklus Kehidupan. Jakarta: Prenada Media Group; 2016.

35. Mukhlisa WNI, Rahayu LS, Furqan M. Asupan Energi dan Konsumsi makanan. Argipa. 2018;3(2):59-66.

36. Ermona NDN, Wirjatmadi B. Hubungan Aktivitas Fisik Dan Asupan Gizi Dengan Status Gizi Lebih Pada Anak Usia Sekolah Dasar Di Sdn Ketabang 1 Kota Surabaya Tahun 2017. Amerta Nutr. 2018;2(1):97.

37. Saint HO, Ernawati. Hubungan aktivitas fisik dengan status gizi pada siswa $X$ dan XII IPA SMAN 7 Surakarta periode 2017 / 2018. Tarumanagara Med Juornal. 2019;2(1):54-8.

38. Rostania M. Pengaruh edukasi gizi terhadap perubahan pengetahuan dan gaya hidup sedentary pada anak gizi lebih di SDN Sudirman I Makassar Tahun 2013. Universitas Hasanuddin; 2013.

39. Ayuni GD, Khomsan A. Hubungan sedentary time, kebiasaan snacking, dan aktivitas fisik dengan status gizi serta komposisi lemak tubuh siswa di SDN Karang Pawulang Kota Bandung. IPB University; 2017.

40. Ernawati F, Pusparini P, Arifin AY, Prihatini M. Hubungan Asupan Lemak Dengan Status Gizi Anak Usia 6 Bulan-12 Tahun Di Indonesia. Penelit Gizi dan Makanan (The J Nutr Food Res. 2019;42(1):41-7. 